\title{
Maternal Spiritual Coping Scale: Development and Validation
}

\author{
K. Gamze Yaman ${ }^{1} \odot$ \\ Marmara University \\ A. Nilgün Canel ${ }^{3}$ \\ Marmara University
}

\author{
Hatice Sanver Gürsoy ${ }^{2}$ \\ University of Maryland Baltimore County
}

\author{
Halil Ekşi ${ }^{4}$ \\ Marmara University
}

Abstract

This research intends to develop a spiritual coping strategies scale for childrearing mothers. The study has been conducted using 24 items and has been carried out on 217 mothers. As a result of factor analysis, items have been categorized under one factor, and the total explained variance has been found to be approximately 0.59. As a result of the study, Cronbach's alpha coefficient for the scale has been found as .966. Item analysis indicates the item-total correlation to be significant $(p<.001)$. All these results show that all items have the same structure. The upper and lower values of the item-total correlations range from .630 to .838. The relationship of the scores from the Religious Coping Scale with those from the Maternal Spiritual Coping Scale has been used for criterion validity. Statistically significant and positive correlations have been found between the subscales of the Maternal Spiritual Coping Scale and Religious Coping Scale; the sub-scales of positive coping $(r=.72 ; p=.01)$ and negative coping $(r=.35 ; p=.01)$ have been determined to significantly correlate. The results of the study show the scale to be a sufficiently valid and reliable measurement tool that can be used to assess the coping strategies mothers use while raising children.

$$
\begin{gathered}
\text { Keywords } \\
\text { Spiritual Coping Strategies Scale } \bullet \text { Spiritual coping } \bullet \text { Mothers }
\end{gathered}
$$

Anne Manevi Başa Çıkma Ölçeği: Geliştirme ve Geçerlik Çalışması

$\ddot{\mathrm{O} z}$

Bu araştırma, çocuk yetiştirmede anneler için manevi baş etme stratejilerini ölçmek amacıyla ölçek geliştirmeyi hedeflemiştir. Çalışma 24 maddeyle yürütülmüş olup ve toplamda 217 anneye ulaşılmıştır. Faktör analizi sonucunda öğeler bir faktör olarak kategorize edilmiş ve açıklanan toplam varyans yaklaşık 0.59 olarak bulunmuştur. Çalışma sonucunda ölçeğin Cronbach alfa katsayısı .966'dır. Madde analizi, madde toplam korelasyonunun anlamlı olduğunu göstermektedir $(p<.001)$. Tüm bu sonuçlar, tüm öğelerin aynı yapı içinde olduğunu göstermektedir. Madde toplam korelasyonlarının alt ve üst değerleri, .630 ile .838 aralığındadır. Kriter geçerliği için kullanılan Dini Başa Çıkma Ölçeği ile Anne Manevi Başa Çı kma Ölçeği skorları arasındaki ilişki ise anlamlı bir ilişkidir. Anne Manevi Başa Çıkma Ölçeği ile Dini Başa Çıkma Ölçeği, Pozitif Başa Çıkma $(r=.72 ; p=.01)$ ve Olumsuz Başa Çı kma $(r=.35 ; p=.01)$ arasında istatistiksel olarak anlamlı pozitif korelasyonlar olduğu belirlenmiştir. Araştırmanın sonuçları, annelerin çocukları yetiştirirken kullandıkları baş etme stratejilerini değerlendirmek için kullanılabilecek yeterince geçerli ve güvenilir bir ölçme aracı olduğunu göstermektedir.

Anahtar Kelimeler

Anne Manevi Başa Çıkma Ölçeği • Manevi başa çıkma • Anneler

1 Correspondence to: K. Gamze Yaman, Department of Educational Sciences, Marmara University, Goztepe Campus, Kadıköy İstanbul 34722 Turkey. Email: gamze.alcekic@marmara.edu.tr

2 Department of Psychology, University of Maryland Baltimore County, 1000 Hilltop Circle, Maryland, US. Email: hsanver@umbc.edu

3 Department of Educational Sciences, Marmara University, Goztepe Campus, Kadıköy İstanbul 34722 Turkey. Email: nilgun.canel@marmara.edu.tr

4 Department of Educational Sciences, Marmara University, Goztepe Campus, Kadıköy İstanbul 34722 Turkey. Email: halileksi@marmara.edu.tr

Citation: Yaman, K. G., Sanver Gürsoy, H., Canel, A. N., \& Ekşi, H. (2018). Maternal Spiritual Coping Scale: Development and validation. Spiritual Psychology and Counseling, 3, 9-21. http://dx.doi.org/10.12738/spc.2018.1.0042 
Research shows that early relationships, especially in relation to the first three years of life, are really important for children's personality and development (Lucion \& Escosteguy, 2011). Parents may encounter various challenges while raising their children. Disturbing behaviors that have been reported during developmental periods, such as whining, resisting parents, and preventing adult activities, are basic parental concerns. Also, parents with more than one child, one of whom is over two years of age, have been seen to experience even greater difficulties (O'Brien, 1995). In Turkey, mothers have an active role and responsibility in childrearing. As parents are role models in life, the relationship between mother and child, a peaceful marriage, and communication with the child are affected by coping strategies that the mother has used while childrearing; therefore, recognizing the coping strategies mothers use when raising their children is considered to be very important. When raising their children, mothers benefit from many different resources, such as social support, marital satisfaction, parental perception, spirituality, and cultural items. Among these, spiritual items can be treated as having received the least focus yet have a special influence in Turkish culture in terms of their success in mothers' coping strategies. When considering the use of mothers' spirituality as a coping strategy for childrearing, one first needs to examine the concept of spirituality.

Spirituality has been defined by Chandler, Holden, and Kolander (1992) as that which is innate and beyond one's egocentric ability, a search for a higher level of knowledge and love. This innate ability is found in every human being but differs for each person in time and capacity. In its definition, the term "to be in a search" means that possible spiritual experiences can only be encountered under certain conditions. Going beyond egocentrism points to the psychological stance that one experiences and evaluates from life events (e.g., how would egocentrism/life events affect my wishes and goals?). Higher levels of knowledge involve high levels of conceptualizing inclusive unity and similarity, but a low focus on differences and duality. Finally, the higher level of love mentioned in the definition is a motivation that leads to selfless acceptance in a paradoxical union and a change for a better result.

When considering Pargament's research and papers in this field, his studies appear to have great significance. Pargament (1999) describes spirituality as the "sacred quest," which he also defined as the foundation of religion. Religion, in contrast to spirituality, is explained as the divine, which some may associate major significance to in explaining the object of the quest, while spirituality explains the significance of a particular object described as a sacred quest. In a more recent definition, Beauregard and O'Leary, the authors and researchers of The Spiritual Brain (2009), have described the meaning of spirituality as any experience that is thought to engage a person in divine communication. Many studies have revealed coping to be related to spirituality. This relationship occurs when individuals become involved in stressful events and seek spiritual paths using spiritual coping strategies (Krok, 2008). 
Pargament (2002) stated that in the moments of stress and crisis, transforming spiritual and religious methods into valid methods of coping has a great influence on one's mental health. Spiritual and religious methods have been seen to influence one's ability to cope with stress and crisis situations and have a positive effect on changes in perspective. Individuals with high spiritual well-being have been found to have more effective coping skills. However, the active role religion plays in the process of coping varies depending on how much religion is involved in one's life. Religion's role in the coping process is limited by its inclusion in one's approach to life. On the contrary, the less important religion is in one's approach to life and life experiences, the less effective it is in the coping process (Ayten, 2012).

Although situations exist where the concept of coping has a positive meaning in the sense of struggling against difficulties, it can also have negative meaning. Thus, coping with distressing situations can have both positive and negative aspects (Pargament, Koenig, \& Perez, 2000). Pargament et al. (1998) used negative and positive patterns while grouping religious coping methods and made a comprehensive description. Positive methods of religious coping include having a sense of faith in the meaning of life, a safe relationship with God, a sense of spirituality and a sense of spiritual connection with other people. Positive methods of religious coping include seeking spiritual support from God, seeking support from clergy or community members, religiously evaluating negative situations, collaborative religious coping, religious help, and forgiving others. On the other hand, methods of negative religious coping involve having a weak relationship pattern with God, a superficial and ominous world concept, and a religious struggle in searching for meaning. Negative methods of religious coping include being angry with God, discontent with community leaders and clergy, and doubtful of God's power and might; considers negative situations as a punishment; and envisions religion pessimistically (Dilmaç, Şimşir, \& Ekşi, 2016).

No studies are found in the literature in Turkey that focus on the changes in emotional states of a mother's spouse and in-laws, nor on children's emotional changes during mothers' childrearing. For this reason, developing the Maternal Spiritual Coping Scale for childrearing has been necessary in order to find out which resources and materials mothers use and to determine if they use any spiritual resources or materials in coping with their feelings during childrearing.

Research and scales are found in the literature examining spiritual coping strategies (Baldacchino \& Buhagiar, 2003; Pargament, Feuille, \& Burdzy, 2011). Various research findings in the literature outside of Turkey show people to use various coping strategies such as friendship and family support, as well as spiritual coping strategies such as worship, during stressful experiences. For example, Baldacchino and Buhagiar (2003) translated the Spiritual Coping Strategies Scale into various 
languages. Findings show the individual coping strategies in response to stressful incidents to be composed of 20 spiritual and non-spiritual Likert-type items.

The Brief RCOPE-Religious Coping Questionnaire consists of 14 items and includes the following sub-dimensions: religious coping methods for find meaning, religious coping methods for gaining control, religious coping methods for gaining comfort and closeness to God, religious coping methods for gaining intimacy with others and closeness to God, and religious coping methods for achieving life transformation (Pargament, Feuille, \& Burdzy, 2011).

Research conducted in Turkey has found efforts in place for developing a scale resembling this matter. For example, the Religious Coping Scale (RCS) measures the frequency of religious counseling and its effectiveness on individuals who have encountered difficult/distressing events and situations. The scale was created by Ayten (2012) using the Religious Coping Scale developed by Pargament, Koenig, and Perez (2000) and used in the study "Take Refuge in God." In this study, the scale's sub-dimensions have been defined as: turning to Allah, positive interpretation, interpersonal religious discontent, religious praying, religious approach, religious transformation, spiritual dissatisfaction, negative interpretation, and searching for the religious path, with the main dimensions being defined as positive and negative religious coping (Ayten, Gocen, Sevinç, \& Öztürk, 2012).

In research conducted in Turkey, several studies are available regarding religious coping scales used by people coping with difficult and stressful situations (Ayten et al., 2012). However, no studies exist that define the spiritual coping strategies parents use for raising children. Considering the fact that parents are the first and most important source of interactions in children's development (Cassidy, 1988), having a study address mothers who have children in early childhood as a group is very important in terms of enabling early intervention. A scale developed in this context can help researchers do similar research and provide support in the context of counseling and family education; additionally, it can be a guiding tool for parental education and support groups, and can lead to comprehensive research and cultural comparisons. Identifying these resources using the developed scale is envisaged to provide important data in planning and development of activities related to these resources. The purpose of this research is to develop a valid and reliable scale for determining how mothers, through their spiritual coping skills, deal with situations that are generally forced upon them.

\section{Method}

This research aims to develop a specific scale for mothers under the conditions of Turkey. Regarding this aim, we have conducted reliability and validity processes. The scale has been created according to a five-point Likert-type scale model. 


\section{Reliability Analyses}

While reliability is defined as a measure for eliminating measurement errors from chance (Turgut, 1990), Crocker and Algina (1986) identify repeatability measures on the same subjects under the same conditions for measuring a particular feature (As cited in Büyüköztürk, Çakmak, Akgün, Karadeniz, \& Demirel, 2016). Cronbach's alpha coefficient has been used to measure the reliability of the Likert scale, as it gives information about the internal consistency/homogeneity of the scale and the reliability of the adapted scale (Tekin, 1993; Tezbaşaran, 1996; Turgut, 1997; Yildırım, 1999; as cited in Otrar, 2007).

In this study, item-total correlations have been made in terms of reliability, with results presented in the findings.

\section{Validity Analyses}

In the scope of validity analysis, an analysis of the principal components that were not rotated has been applied in order to determine the factor structure of the scale. We decided the factor analysis could be interpreted by looking at the results of the KMO and Bartlett sphericity tests.

In this study, the Religious Coping Scale (Pargament, Koenig, \& Perez, 2000) has been used for criterion validity, with the results presented in the findings.

\section{Process}

Based on the content of the preliminary study with mothers, the researchers added to the items, creating a pool of 24 items. Forming the spiritual sub-dimension was inspired by the positive religious and spiritual coping strategies of Lucero, Pargament, Mahoneyand, and DeMaris (2013) and the positive religious coping skills from the Religious Coping Scale which was adapted to Turkish by Eksi and Sayin (2016). The form created after shaping the items was examined by 10 teaching staff (five evaluation experts and five psychological counseling and guidance experts) experts, each with at least a doctoral degree in the field, and expert opinions were taken in writing on whether the behaviors of the produced items are indicative of the relevant spiritual coping strategies.

Experts were asked to indicate their answers on the scale regarding the appropriateness of the involved factors using a 3-point scale (appropriate, appropriate but need to correct/ amended proposal, inappropriate). Space was left atop each item for experts to write a correction proposal. In accordance with the experts' opinions, Items $2,3,7$, and 8 (50\%), Items 1, 5, 11, 12, and $20(66 \%)$, and Items 4 and 14 (83\%) were decided upon for revision while the remaining items were retained. After considering the experts' opinions, changes were made to correct the items that had been reported. After these 
operations, we decided the draft scale would consist of 24 items. The researcher prepared a detailed guideline on how to apply the scale and designed the 5-point Likert-type form to include relevant demographic questions, making it both available online and in printed form. After completing the applications, all response forms were examined and entries were made using SPSS; missing values were examined. Assigning missing values was made by taking averages. Only three of the 220 participants were excluded. As a result, analysis of the scale development began with a sample of the remaining 217 .

\section{Participants}

Participants consist of mothers between 27-51 years old with one or more children. Mothers' marital status was not considered within the scope of the study. Their education level was determined to be high school or higher. Participants were reached both through online surveys and schools.

\section{Measures}

Maternal Spiritual Coping Scale. A sample of items developed in this study are presented in the Appendix. The scale is scored using a 5-point Likert scale where 5 $=$ strongly agree and 1 = strongly disagree. In the end, the scale has no negative or reverse-scored items. The higher a person's score on the scale, the more a mother uses spiritual ways of coping when encountering forced situations.

As a result of the factor analysis, items have been categorized into one factor and the total explained variance is found to be approximately 0.59 . As a result of the study, Cronbach's alpha coefficient of the scale is .966. Item analysis indicates the item-total correlation to be significant $(p<.001)$. All these results show each item to have the same structure. The lower and upper values of item-total correlations are between .630 and .838 .

Religious Coping Scale. The Religious Coping Scale, consisting of 10 items and adapted to Turkish by Sayın and Ekşi (2016), was applied to adults/young adults and scored on a 4-point Likert scale. The scale consists of two subscales. Scores that can be taken from the subscale of positive religious coping range from 7 to 28 , and scores that can be taken from the subscale of negative religious coping range from 3 to 12 . No reverse items are found in the scale.

\section{Results}

\section{Item Analysis Results}

We looked at item discrimination analysis and the total correlation of items in order to determine which of the 24 items in the measurement works. Item-total test 
correlation explains the relationship between the scores obtained from the test items and the total score of the test (Büyüköztürk, 2004). In this frame, the correlations between item scores and the total score of the scale are shown in Table 1. Reliability analysis has been started for factors created after this process.

\begin{tabular}{|c|c|c|c|}
\hline \multirow[t]{2}{*}{ Item } & \multicolumn{2}{|c|}{ Total Score } & \multirow[b]{2}{*}{$p$} \\
\hline & $N$ & $r$ & \\
\hline 1 & 217 & .690 & .000 \\
\hline 2 & 217 & .717 & .000 \\
\hline 3 & 217 & .774 & .000 \\
\hline 4 & 217 & .813 & .000 \\
\hline 5 & 217 & .809 & .000 \\
\hline 6 & 217 & .795 & .000 \\
\hline 7 & 217 & .630 & .000 \\
\hline 8 & 217 & .743 & .000 \\
\hline 9 & 217 & .740 & .000 \\
\hline 10 & 217 & .763 & .000 \\
\hline 11 & 217 & .682 & .000 \\
\hline 12 & 217 & .656 & .000 \\
\hline 13 & 217 & .744 & .000 \\
\hline 14 & 217 & .815 & .000 \\
\hline 15 & 217 & .748 & .000 \\
\hline 16 & 217 & .646 & .000 \\
\hline 17 & 217 & .788 & .000 \\
\hline 18 & 217 & .644 & .000 \\
\hline 19 & 217 & .838 & .000 \\
\hline 20 & 217 & .823 & .000 \\
\hline 21 & 217 & .807 & .000 \\
\hline 22 & 217 & .744 & .000 \\
\hline 23 & 217 & .634 & .000 \\
\hline 24 & 217 & .670 & .000 \\
\hline
\end{tabular}

${ }^{*} p<.001$

As interpreted from Table 1, all items in the item-total analyses are shown to be significant. Significant correlations were achieved at the lowest level of significance. All these results show all items to have the same structure.

\section{Results of the Validity Analyses}

The Kaiser-Meyer-Olkin sampling-suitability coefficient was calculated first to examine the adequacy of the data for exploratory factor analysis (.94); Bartlett sphericity X2 test value was found to be 4,811.211 $(S D=276)$ and significant ( $p<$ $.001)$. The factor structure is limited to 1 because the projected structure of the scale is a one-factor structure. The explanatory factor analysis results are given in Table 2. 


\section{Factor Analysis Results for the Maternal Spiritual Coping Scale}

Factor analysis was performed primarily to determine the groupings (factors) among items for the validity procedures. In the process of factor analysis, KMO and Bartlett values were determined, basic component analysis was carried out, and factor loads were determined. Figure 1 shows the scree plot, and Table 2 the factor loading values. Figure 1 and Table 2 show one main dimension to have been identified as a result of factor analysis. Factor analysis utilizes varimax rotations and determined four factors, the first explains $58.6 \%$ of the total variance; the second, $5.4 \%$; the third, 4.6\%; and the fourth, 4.2\%. However, the required final analysis did not return a single factor, the results of which are presented below.

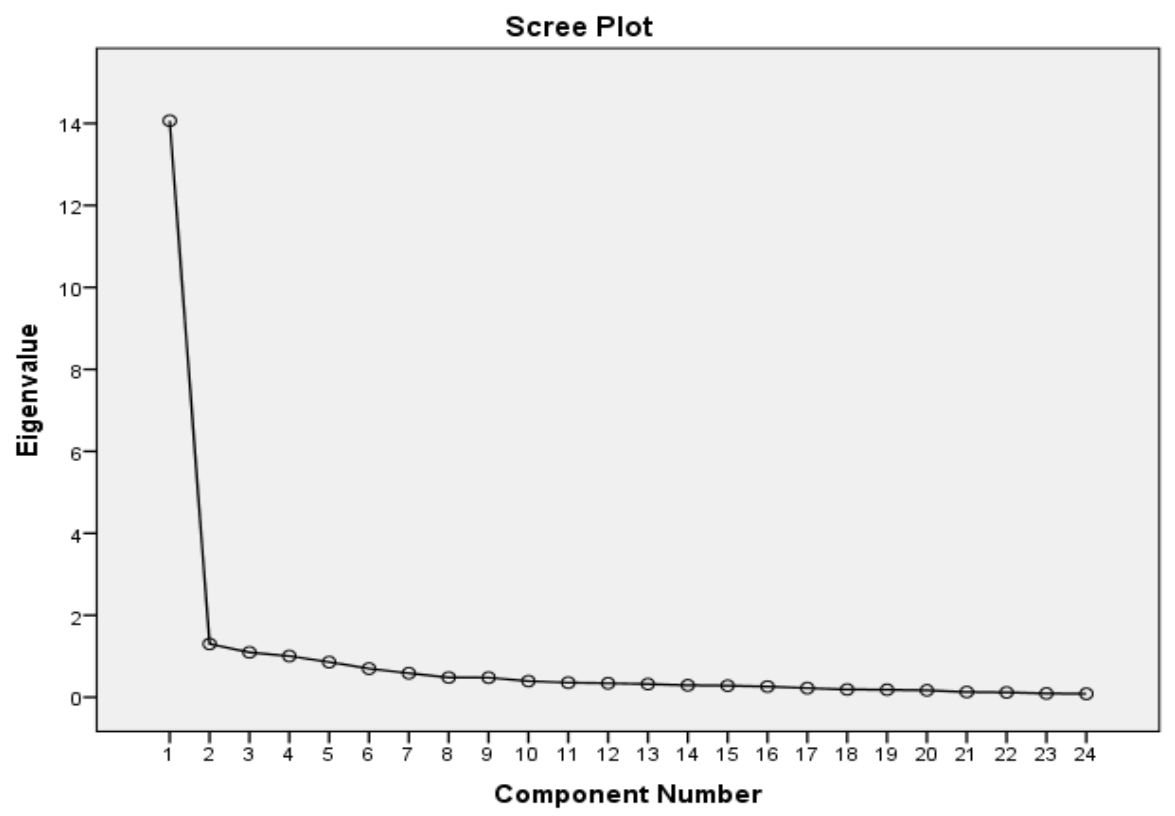

Figure 1. Scree plot.

Factor analysis began with 24 items. Analysis results were analyzed and descriptive factor analysis was performed by limiting the factor number to 1 as predicted. No item in the cumulative percentage column has a value below 30 . This formed 1-factorial structure accounts for $58.604 \%$ of the total variance. No item is seen to have a high value in more than one factor; each item value is in only one factor. The resulting factor-load values are given in Table 3. 
Table 2

Factor Analysis Results

\begin{tabular}{|c|c|c|c|c|c|c|}
\hline \multirow[t]{2}{*}{ Component } & \multicolumn{3}{|c|}{ Initial Eigenvalues } & \multicolumn{3}{|c|}{$\begin{array}{c}\text { Total Variance Explained } \\
\text { Extraction Sums of Squared Loadings }\end{array}$} \\
\hline & Total & \%of Variance & Cumulative\% & Total & \%of Variance & Cumulative\% \\
\hline 1 & 14.065 & 58.604 & 58.604 & 14.065 & 58.604 & 58.604 \\
\hline 2 & 1.300 & 5.418 & 64.022 & & & \\
\hline 3 & 1.095 & 4.561 & 68.583 & & & \\
\hline 4 & 1.004 & 4.185 & 72.768 & & & \\
\hline 5 & .857 & 3.572 & 76.340 & & & \\
\hline 6 & .698 & 2.910 & 79.250 & & & \\
\hline 7 & .585 & 2.438 & 81.688 & & & \\
\hline 8 & .481 & 2.006 & 83.695 & & & \\
\hline 9 & .479 & 1.996 & 85.690 & & & \\
\hline 10 & .394 & 1.642 & 87.332 & & & \\
\hline 11 & .356 & 1.484 & 88.816 & & & \\
\hline 12 & .341 & 1.419 & 90.235 & & & \\
\hline 13 & .322 & 1.342 & 91.578 & & & \\
\hline 14 & .291 & 1.214 & 92.792 & & & \\
\hline 15 & .282 & 1.176 & 93.968 & & & \\
\hline 16 & .261 & 1.088 & 95.056 & & & \\
\hline 17 & .223 & .928 & 95.984 & & & \\
\hline 18 & .191 & .795 & 96.779 & & & \\
\hline 19 & .183 & .763 & 97.542 & & & \\
\hline 20 & .168 & .700 & 98.242 & & & \\
\hline 21 & .127 & .529 & 98.771 & & & \\
\hline 22 & .119 & .495 & 99.266 & & & \\
\hline 23 & .092 & .383 & 99.649 & & & \\
\hline 24 & .084 & .351 & 100.000 & & & \\
\hline
\end{tabular}

Table 3

Factor Loadings of the One Factor Solution

\begin{tabular}{cccc}
\hline Items & Component & & \\
\hline & $\mathbf{1}$ & & .768 \\
\hline Item 19 & .843 & Item 9 & .766 \\
Item 4 & .838 & Item 22 & .757 \\
Item 20 & .837 & Item 13 & .731 \\
Item 14 & .831 & Item 2 & .727 \\
Item 21 & .826 & Item 11 & .722 \\
Item 6 & .819 & Item 1 & .705 \\
Item 5 & .818 & Item 24 & .694 \\
Item 17 & .816 & Item 12 & .683 \\
Item 10 & .804 & Item 23 & .673 \\
Item 3 & .793 & Item 16 & .668 \\
Item 15 15 & .776 & Item 18 & .651 \\
Item 8 & .771 & Item 7 & \\
\hline
\end{tabular}

The final scale consists of 24 items, and the Maternal Spiritual Coping Scale AMB-Ö) was chosen for a name. 


\section{Reliability Statistics}

The internal consistency coefficient of the AMB-Ö is quite high. Cronbach's alpha value is $\alpha=.966$.

\section{Criterion Validity}

In order to determine criterion validity for the AMB-Ö, we applied the Religious Coping Scale, which has been adapted to Turkish and tested for reliability and validity by Eksi and Sayin (2016). The specified test was applied to 68 people. Statistically significant and positive correlations have been found for the subscales of the Maternal Spiritual Coping Scale with the Religious Coping Scale, a significant correlation has been determined for positive coping $(r=.72 ; p=.01)$ with negative coping $(r=.35 ; p=.01)$.

\section{Discussion}

This study has aimed to develop a scale in order to determine how mothers use religious coping in situations forced upon them while raising children. According to Büyüköztürk (2012), KMO sample coefficient values of .80 or higher show appropriateness and conformity for using explanatory factor analysis after forming the items and collecting data. The X2 value of the Bartlett sphericity test shows significance; and factor loadings measure greater than .30 . In this study, $K M O=$ .94 and the Bartlett sphericity test X2 value show a $p<.001$. As seen in light of the research findings, the scale is found to consist of one sub-dimension (spiritual coping) and 24 items. As a result of factor analysis, items have been categorized into one factor, and the total explained variance is found to be approximately 0.59 . These values also show evidence conformity.

As a result of the study, Cronbach's alpha coefficient of the scale has been found as .966. Item analysis indicates the item-total correlations to be significant $(p<.001)$. These results show all items to have the same structure. The upper and lower values of item-total correlations range from .630 to .838 . Statistically significant and positive correlations exist between the subscales of Maternal Spiritual Coping Scale and Religious Coping Scale; the subscales of positive coping $(r=.72 ; p=.01)$ and negative coping $(r=.35 ; p=.01)$ have been determined to significantly correlate. The results of the study show the scale to be a sufficiently valid and reliable measurement tool that can be used to assess mothers' coping strategies used while raising children. This scale has been proven to be valid and reliable for measuring mothers' spiritual coping.

Lucero, Pargament, Mahoney, and DeMaris (2013) set out certain positive and negative religious and spiritual coping strategies in their research on the link between religious and spiritual coping and cohesion that parents use during pregnancy. The positive religious and spiritual coping strategies were stated as: reconsidering 
through religious optimism (redefining the stress factors in one's life by interpreting them favorably through religion), collaborative religious coping (quest for taking control through partnership with God), effective religious submission (leaving control completely to God in order to cope), seeking spiritual support (seeking peace and security through the love and mercy of God), spiritual bond (the individual's experience of independency through transcendental thoughts), seeking support from community or clergy (seeking peace and security through the love and mercy of congregation and clergy), and worshipping (parents' prayers for the sake of the baby and pregnancy). From these sub-dimensions, the spiritual dimension used in Turkey appears compatible with that of worshipping. This shows the study's relevance to the international literature.

The literature contains research conducted on mothers' use of spiritual resources and seems to support this use. The case also exists that this study introduces spiritual coping as an original concept and is a psychometric examination of this premise.

The scale obtained is considered as a guide for individual and group studies, especially for mothers. In the direction of the results revealed by this scale, new problem areas can be considered for researchers to focus on. For example, determining the spiritual coping strategies of fathers and comparing them to mothers', comparing the results obtained from different provinces of Turkey, or determining the source of these strategies can be considered as examples for future research. Details such as the study being crosssectional and lacking a test-retest can be considered as limitations of the research.

\section{References}

Ayten, A., Göcen, G., Sevinç, K., Öztürk, E. E. (2012). Dini Başa Çıkma, Şükür ve Hayat Memnuniyeti İlişkisi: Hastalar, Hasta Yakınları ve Hastane Çalışanları Üzerine Amprik Bir Araştırma [ The relationship of religious coping, thanfulness, and life satisfaction: An empirical research on patients, those close to them, and hospital employees]. Din Bilimleri Akademik Araştırma Dergisi, 12(2), 45-79.

Baldacchino, D. R., \& Buhagiar, A. (2003). Psychometric evaluation of the Spiritual Coping Strategies scale in English, Maltese, back-translation and bilingual versions. Journal of Advanced Nursing, 42(6), 558-570.

Beauregard, M., \& O'Leary, D. (2009). The spiritual brain. A neuroscientist's case for the existence of the soul. New York, NY: Harper Collins Publishers.

Bornstein, M. H. (2012). Cultural approaches to parenting. Parenting: Science and Practice, 12(23), 212-221.

Bornstein, M. H. (2015). Culture, parenting, and zero-to-threes. Child and Family Research, Mart, 2-9.

Büyüköztürk, Ş. (2012). Sosyal bilimler için veri analizi el kitabı [The data analysis handbook for the social sciences], (17th ed.). Ankara, Turkey: Pegem Akademi Yayınları.

Büyüköztürk, Ş., Cakmak, E. K., Akgün, Ö. E., Karadeniz, Ş., \& Demirel, F. (2016). Bilimsel Araştırma Yöntemleri [Scientific Research Methods]. Ankara: Pegem Akademi. 
Cassidy, J. (1988). Child-mother attachment and the self in six-year-olds. Child Development, 59(1), 121-134.

Chandler, C. K., Holden, J. M., \& Kolander, C. A. (1992). Counseling for spiritual wellness: Theory and practice.Journal of Counseling \& Development, 71(2), 168-175.

Dilmaç, B., Ekşi, F., \& Şimşir, Z. (2016, December). Psikolojik danışma deneyimi yaşayanların dini başa çıkma, psikolojik iyi olma ve affetme düzeyleri arasındaki yordayıcı ilişkiler: Bir model önerisi [The predictive relationship among the levels of religious coping, psychological well-being, and forgiveness for those undergoing psychological counseling: An example model]. First International Congress on Religious-Spiritual Counselling \& Care. Istanbul.

Ekşi, H. \& Sayın, M. (2016, May). The adaptation of Religious Coping Scale into Turkish language: A study of bilingual equivalance, validity and reliability. Paper presented at the AGP Humanities and Social Sciences Conference, BAU International Berlin University, Berlin, Germany.

Huang, W. J. (2005). An Asian perspective on relationship and marriage education. Family process, 44(2), 161-173.

Krok, D. (2008). The role of spirituality in coping: Examining the relationships between spiritual dimensions and coping styles. Mental Health, Religion \& Culture, 11(7), 643-653.

Kuo, B. C., Roysircar, G., \& Newby-Clark, I. R. (2006). Development of the Cross-Cultural Coping Scale: Collective, avoidance, and engagement coping. Measurement and Evaluation in Counseling and Development, 39(3), 161.

Lam, A. G., \& Zane, N. W. S. (2004). Ethnic differences in coping with interpersonal stressors. Journal of CrossCultural Psychology, 35(4), 446-459.

Lazarus, R. S., \& Folkman, S. (1984). Stress, appraisal, and coping. New York, NY: Springer.

Lucero, S. M., Pargament, K. I., Mahoney, A., \& DeMaris, A. (2013). Links between religious and spiritual coping and adjustment among fathers and mothers during first pregnancy. Journal of Reproductive and Infant Psychology, 31(3), 309.

Lucion, M. \& Escosteguy N. (2011). Mother-caregivers twins relationship in the first year after birth. Rev Bras Crescimento Desenvolvimento Hum, 21(2), 307-318.

O'Brien, M. (1996). Child-rearing difficulties reported by parents of infants and toddlers. Journal of Pediatric Psychology, 21(3), 433-446.

Otrar, M. (2007). Marmara öğrenme stilleri ölçeğinin (ÖSÖ-M) geçerlik ve güvenirlik çalışması. Kuram ve Uygulamada Eğitim Bilimleri, 7(3), 1379-1419.

Pargament, K., Feuille, M., \& Burdzy, D. (2011). The Brief RCOPE: Current psychometric status of a short measure of religious coping. Religions, 2(1), 51-76.

Pargament, K. I. (1999). The psychology of religion and spirituality? Yes and no. International Journal for the Psychology of Religion, 9(1), 3-16.

Pargament, K. I. (2002). The bitter and the sweet: An evaluation of the costs and benefits of religiousness. Psychological Inquiry, 13(3), 168-181.

Perricone, G., Guerra, M. P., Cruz, O., Polizzi, C., Lima, L., Morales, M. R., Lemos, M. S. \& Fontana, V. (2013). Maternal coping strategies in response to a child's chronic and oncological disease: A cross-cultural study in Italy and Portugal. Pediatric Reports, 5(2), 43.

Rosenthal, M. K., \& Roer-Strier, D. (2001). Cultural differences in mothers' developmental goals and ethnotheories. International Journal of Psychology, 36(1), 20-31.

Wei, R. (2007). The role of culture in the process of coping with stress. Unpublished doctoral dissertation, Cornell University, Ithaca, NY. 


\section{Appendix}

\section{Maternal Spiritual Coping Scale}

Below are lists of items that indicate what mothers do to try and cope with the forced situations while childrearing. Please read each of the items carefully and decide how appropriate these items are to your situation by looking at the following score and marking the appropriate box.

5- Strongly agree

4- Agree

3- Neither agree nor disagree

2- Disagree

1- Strongly disagree

Please respond to all questions by considering your experience as a mother.

\begin{tabular}{|l|l|l|l|l|l|l|}
\hline & \multicolumn{1}{|l|}{} & $\mathbf{5}$ & $\mathbf{4}$ & $\mathbf{3}$ & $\mathbf{2}$ & $\mathbf{1}$ \\
\hline 5. & $\begin{array}{l}\text { I would remind myself of Prophet Mohammed's (saws) advice to } \\
\text { stay calm. }\end{array}$ & & & & \\
\hline 20. & It is motivating to think parenting is a great form of worship. & & & & & \\
\hline 23. & I am thankful for the existence of my children. & & & & & \\
\hline
\end{tabular}


